\title{
STRATEGIC INTERACTION ON LOCAL SPENDING: EVIDENCE FROM JAPANESE MUNICIPALITIES
}

\section{Nguyen Tuan Dung}

${ }^{1}$ Graduate School of Economics, Kyushu University, ${ }^{2} T N U$ - International School

\begin{tabular}{|c|c|c|}
\hline \multicolumn{2}{|c|}{ ARTICLE INFO } & ABSTRACT \\
\hline Received: & $16 / 4 / 2021$ & On March 11, 2011, the Great East Japan Earthquake struck the North- \\
\hline Revised: & $29 / 5 / 2021$ & $\begin{array}{l}\text { eastern part of Japan, triggered a series of disasters, destructed the } \\
\text { Japanese economy, and caused extensive damage to infrastructures and }\end{array}$ \\
\hline Published: & $31 / 5 / 2021$ & supply chain. In a national effort to mobilize all efforts towards the \\
\hline \multicolumn{2}{|l|}{ KEYWORDS } & ce their local expenditures. This study empirically examines whether \\
\hline \multicolumn{2}{|l|}{ Strategic interaction } & employing a spatial econometric approach on a sample of 363 \\
\hline \multicolumn{2}{|c|}{ Japanese municipalities } & municipalities that were severely affected by the disaster. The spatial \\
\hline \multicolumn{2}{|c|}{ Municipal spending } & autoregressive model with spatial error correlation was chosen through \\
\hline \multicolumn{2}{|c|}{ Yardstick competition } & $\begin{array}{l}\text { valid tests, and was estimated by generalized spatial two-stage least } \\
\text { squares estimator. The results indicate evidence of such strategic }\end{array}$ \\
\hline \multicolumn{2}{|l|}{ Spatial econometrics } & $\begin{array}{l}\text { interaction among neighboring municipalities. The robustness check tests } \\
\text { using maximum likelihood estimation also show comparable results. It is } \\
\text { suggested that the Japanese municipalities in the study sample may } \\
\text { consider their neighbors' choices in making local expenditure decisions. }\end{array}$ \\
\hline
\end{tabular}

\section{TƯƠNG TÁC CHIẾN LƯợC TRONG CHI TIÊU CHÍNH PHỦ: BẰNG CHÚNG TỪ CHÍNH QUYỀN ĐỊA PHƯƠNG TẠI NHậT BẢN}

Nguyễn Tuấn Dũng

${ }^{1}$ Khoa Kinh tế Sau Đại học, Đại học Kyushu, ${ }^{2}$ Khoa Quốc tế - ĐH Thái Nguyên

\begin{tabular}{|c|c|c|}
\hline \multicolumn{2}{|c|}{ THÔNG TIN BÀI BÁO } & \multirow{3}{*}{$\begin{array}{l}\text { TÓM TÁT } \\
\text { Vào ngày } 11 \text { tháng } 3 \text { năm 2011, một trận động đất quy mô lớn đã xảy } \\
\text { ra ở phía Đông Bắc Nhật Bản, tạo ra một chuối các thảm họa, phá hủy }\end{array}$} \\
\hline Ngày nhận bài: & $16 / 4 / 2021$ & \\
\hline Ngày hoàn thiện: & 29/5/2021 & \\
\hline Ngày đăng: & $31 / 5 / 2021$ & và chuỗi cung ứng. Nằm trong nỗ lực toàn quốc nhằm huy động mọi \\
\hline \multirow{2}{*}{\multicolumn{2}{|c|}{ TÙ' KHÓA }} & $\begin{array}{l}\text { nguon lực hương tờ ke hoạch ho1 phục quoc gia, chinh phu trung ương } \\
\text { Nhât Bản đã vêu cầu tất cả các chính quvền đia phương giảm chi tiêu }\end{array}$ \\
\hline & & tai đia phương của mình. Bằng phương pháp tiếp cân kinh tế lương \\
\hline \multirow{10}{*}{\multicolumn{2}{|c|}{$\begin{array}{l}\text { Tương tác chiến lược } \\
\text { Chính quyền địa phương } \\
\text { Chi tiêu chính phủ } \\
\text { Cạnh tranh so sánh } \\
\text { Kinh tế lượng không gian }\end{array}$}} & không gian trên dữ liệu của 363 thành phố bị ảnh hưởng nặng nề bởi \\
\hline & & thiên tai, bài báo kiểm tra thực nghiệm về tính phụ thuộc lẫn nhau \\
\hline & & eết định của chính quyền địa phương trong tổng mức chi \\
\hline & & $\begin{array}{l}\text { tieu tren địa ban. Mo hinh tự ho1 quy khong gian cung sa1 so khong } \\
\text { gian được lưa chon dưa trên kết quả của các kiểm đinh hợp lê. Mô hình }\end{array}$ \\
\hline & & được ước lượng bởi phương pháp bình phương nhỏ nhất hai giai đoạn \\
\hline & & không gian tổng quát. Kết quả chỉ ra bằng chứng về sự tương tác chiến \\
\hline & & lược giữa các chính quyền địa phương lân cận trong mẫu nghiên cứu. \\
\hline & & Phương pháp kiểm tra tính vững của mô hình sử dụng ước lượng hợp \\
\hline & & lý cực đại cũng xác nhận kết quả trên. Kết quả bài báo gợi ý rằng các \\
\hline & & $\begin{array}{l}\text { chính quyền địa phương tại Nhật Bản có thể đã xem xét, cân nhắc các } \\
\text { lựa chọn của chính quyền lân cận khi đưa ra các quyết định về ngân } \\
\text { sách tại địa phương mình. }\end{array}$ \\
\hline
\end{tabular}

DOI: $\underline{\text { https://doi.org/10.34238/tnu-jst.4374 }}$

Email: dzung@tnu.edu.vn 


\section{Introduction}

Horizontal strategic interaction among jurisdictions in government spending has been studied broadly in the past thirty years. Previous empirical works have shown shreds of evidence that confirm the hypothesis that local jurisdictions do not make spending decisions in isolation. Case et al. [1] are popularly considered the first ones who formalized the notion of expenditures of neighboring jurisdictions as an important determinant of own government expenditures.

Prior research on strategic interaction on government expenditures are diverse in categories of spending as well as researching countries, including total expenditure in Indonesia [2], current expenditure in Italy [3] as well as different sub-categories like culture in Sweden [4], education in China [5], industry-infrastructure in Czech [6], and business development in the US [7], to name a few. However, previous evidence drawn from quasi-experimental approach employing exogenous variation is scarce. Quasi-experimental settings that provide exogenous variation in the variable of interest are required to consistently estimate the causal spatial interaction parameters in the field of spatial econometrics [8] - [10].

To fill this gap, this paper aims to estimate the responses of Japanese municipalities to changes in municipal spending in their neighboring municipalities, using the number of houses destroyed by the Great East Japan Earthquake (GEJE) - the most powerful earthquake ever recorded in Japan and one of the most costly earthquakes in human history - in each municipality are used as a source of exogenous variation in local spending. We built a spatial model that examined both interdependences in spatial lag and spatial error. The model was estimated by the Generalized Spatial Two-Stage Least Squares estimator (GS2SLS) and was robustly checked by maximum likelihood. Our results indicate that spatial interactions of total local public expenditures among 363 municipalities in the sample exist and statistically significant at conventional levels. This paper contributes to the modest literature that makes use of an exogenous variation source for the identification of spatial strategic interaction among the municipalities in a quasi-experimental approach.

The rest of the paper is structured as follows: Section 2 provides descriptions of the methodology. Section 3 specifies reports the results. Finally, Section 4 concludes the main content of the research and provides some recommendations.

\section{Methodology}

\subsection{Data}

Our sample consists of annual data on 363 municipalities over 07 fiscal years (FY2010FY2016), collected from Japanese official government statistics websites. The descriptive statistics as shown in Table 1 give an overview of variables in two financial years 2010 and 2014.

The dependent variable is the total municipal expenditure per capita. Sets of control variables are employed to capture municipal variation in terms of demography, socio-economics, and fiscal capacity. Regarding demographic attributes, we included population density, and proportions of the population aged below 15 and over 65. Concerning socio-economic attributes, we collected data on the municipal unemployed rate, grant ratio from upper-tier governments, and per capita taxable income. Fiscal capacity may affect the ability of local jurisdictions to make independent fiscal decisions. Therefore, data on municipal cumulative debt rates and grant ratios from uppertier governments over total municipal revenue were collected.

A key variable to ensure an exogenous variation of the sample is the variable on the number of residential houses destroyed by the GEJE in each municipality. There are three levels of housing destruction in source data, so we assign values of $0.2,0.5$, and 1 for each partial, half and total housing damages respectively. A variable on central government grants for reconstructing 
the local infrastructure and economy after GEJE was added to control variation in consequences of the disasters upon the municipalities in the sample.

Six variables, namely total expenditures per capita, population density, taxable income per capita, number of houses destroyed, and grants for GEJE reconstruction, were transformed into natural logarithm form.

The inverse distance matrix was chosen for this study to ensure the exogenous trait of the spatial weight matrix's elements. Since the areas of Japanese municipalities are relatively small, we truncated the matrix at $60 \mathrm{~km}$ following Miyazaki and Sato [11]. Each row of the matrix was normalized.

Table 1. Summary statistics

\begin{tabular}{lcccccccc}
\hline & \multicolumn{2}{c}{ Mean } & \multicolumn{2}{c}{ Std. Dev } & \multicolumn{2}{c}{ Min } & \multicolumn{2}{c}{ Max } \\
\hline & $\mathbf{2 0 1 0}$ & $\mathbf{2 0 1 6}$ & $\mathbf{2 0 1 0}$ & $\mathbf{2 0 1 6}$ & $\mathbf{2 0 1 0}$ & $\mathbf{2 0 1 6}$ & $\mathbf{2 0 1 0}$ & $\mathbf{2 0 1 6}$ \\
\hline $\begin{array}{l}\text { Dependent variable } \\
\text { Total expen. }\end{array}$ & 418.66 & 571.32 & 180.69 & 663.95 & 233.71 & 248.31 & 1679.63 & 10799.48 \\
Independent variables & & & & & & & & \\
Pop. density & 1406.0 & 1417.0 & 2522.6 & 2580.73 & 7.2 & 6.15 & 14020 & 14170.84 \\
Pop. share < 15y & 12.74 & 11.69 & 1.66 & 1.71 & 6.93 & 6.36 & 18.19 & 17.17 \\
Pop. share > 65y & 24.93 & 29.97 & 5.28 & 5.38 & 11.70 & 16.35 & 53.2 & 55.16 \\
Taxable income & 2.84 & 2.91 & 0.45 & 0.44 & 2.01 & 2.07 & 4.69 & 5.18 \\
Cumulative debt rate & 94.62 & 88.35 & 23.67 & 27.52 & 4.03 & 7.11 & 201.94 & 176.91 \\
Unemployed rate & 6.66 & 3.90 & 1.50 & 0.93 & 3.15 & 1.67 & 19.73 & 11.21 \\
Grant ratio & 34.99 & 32.63 & 15.02 & 12.42 & 3.69 & 6.72 & 72.57 & 65.89 \\
GEJE grant & 0 & 425611.7 & 0 & 1706513 & 0 & 0 & 0 & $1.95 e+07$ \\
Houses destroyed & 0 & 1087.8 & 0 & 6312.8 & 0 & 0.2 & 0 & 108047.7 \\
\hline
\end{tabular}

Notes: Total expen. $=$ total expenditures, per capita and in thousand yen unit; Pop. = population; $y=$ years old; Taxable income is per taxpayer and in thousand yen unit; GEJE grant is per capita and in thousand yen unit. Source: Author's own calculation.

\subsection{Empirical strategy}

First, a non-spatial linear regression model (OLS) was estimated to test whether the model needs to be extended with the inclusion of spatial interaction effects. Moran'I test has been popularly employed as a specification test for spatial autocorrelation. As can be seen in Table 2, The P-value of Moran's I test was statistically significant, so we could reject the null hypothesis of no spatial autocorrelation. Furthermore, Lagrange Multplier (LM) and Robust LM statistics were used to examine the possible existence of spatial autocorrelation in the dependent variable and/or in the error term. The P-value of all LM and Robust LM tests were highly significant, so we could reject the null hypotheses of spatial independence, which were $\lambda=0$ and/or $\rho=0$. Based on the statistics in Table 2, the spatial autoregressive model with spatial error correlation (SARAR) was selected.

Table 2. Diagnostics tests for spatial dependence

\begin{tabular}{lcc}
\hline Specification Test & Coefficient & P-value \\
\hline Moran's I (error) & 10.1612 & 0.0000 \\
Lagrange Multiplier (lag) & 79.7167 & 0.0000 \\
Robust LM (lag) & 10.9029 & 0.0000 \\
Lagrange Multiplier (error) & 133.3521 & 0.0000 \\
Robust LM (error) & 64.5383 & 0.0000 \\
Lagrange Multiplier (LM lag+ LM error) & 144.2550 & 0.0000 \\
\hline
\end{tabular}

A typically estimated equation of the SARAR model can be written as: 


$$
y=\lambda W y+X \beta+u, u=\rho W u+\varepsilon
$$

where $y$ is an $N \times 1$ vector of per capita municipal expenditure, $W y$ is the corresponding spatially lagged dependent variable for the weights matrix $W, X$ is an $N \times K$ matrix of explanatory variables, and $\beta$ is a $K \times 1$ vector of estimated parameters. The $N \times 1$ vector of error terms $-u-$ is assumed to follow a spatial autoregressive process; and $\varepsilon$ is an $N \times 1$ vector of white noise errors. $\lambda$ (strategic interaction) and $\rho$ (error interaction) are spatial lag parameters. Specifically, $\lambda$ (Lambda) is a spatial autoregressive parameter that measures the magnitude of strategic interaction among the municipalities.

Since what we concern is how the changes in public expenditure of neighboring municipalities affect changes in expenditure in own municipality, we employed the following equation explicitly considers how changes in the right-hand side over time affect the change in $y$ over the same period:

$$
\Delta Y=\lambda W \Delta Y+\Delta X \beta+\Delta u, \quad \Delta u=\rho W \Delta u+\varepsilon
$$

We took various periods for differencing in two-year intervals, including differences from 2010 to 2012, from 2012 to 2014, and from 2014 to 2016.

For main analysis, the model was estimated by GS2SLS. Details of GS2SLS procedures can be found in Kelejian and Prucha [12], [13]. Since GS2SLS provides more consistent estimates than ML in heteroskedastic cases [14], the option heteroskedastic is added in GS2SLS steps. The maximum likelihood estimator was then further tested for robustness check.

\section{Results}

Table 3. Spatial interactions in total expenditures among the Japanese municipalities (GS2SLS)

\begin{tabular}{lccc}
\hline$\Delta$ Total expenditures & $\Delta \mathbf{2 0 1 0 - 2 0 1 2}(\mathbf{1})$ & $\Delta \mathbf{2 0 1 2 - 2 0 1 4}(\mathbf{2})$ & $\Delta \mathbf{2 0 1 4 - 2 0 1 6}(\mathbf{3})$ \\
\hline$\Delta$ Population density & $-4.710 * * *(0.957)$ & $0.262(0.530)$ & $-1.427 * * *(0.223)$ \\
$\Delta$ Share of population $<15$ & $0.108(0.060)$ & $-0.077(0.041)$ & $0.012(0.024)$ \\
$\Delta$ Share of population $>65$ & $0.006(0.025)$ & $0.016(0.011)$ & $0.008(0.007)$ \\
$\Delta$ Taxable income & $1.561(0.923)$ & $0.250(0.443)$ & $0.069(0.240)$ \\
$\Delta$ Unemployed rate & $0.014(0.013)$ & $0.019(0.015)$ & $0.020(0.016)$ \\
$\Delta$ Grant ratio & $0.010 * * *(0.002)$ & $0.003 *(0.001)$ & $0.002(0.002)$ \\
$\Delta$ Cumulative debt rate & $-0.012 * * *(0.001)$ & $-0.008 * * *(0.001)$ & $-0.007 * * *(0.001)$ \\
$\Delta$ GEJE grant & $0.009(0.012)$ & $0.003(0.008)$ & $0.017 *(0.008)$ \\
Houses destroyed & $0.001(0.004)$ & $-0.003(0.002)$ & $-0.001(0.002)$ \\
Lambda & $0.163 *(0.082)$ & $0.553 * * *(0.106)$ & $0.458 * * *(0.104)$ \\
Rho & $0.416 * *(0.170)$ & $-0.360 *(0.183)$ & $-0.251(0.226)$ \\
Observations & 363 & 363 & 363 \\
\hline
\end{tabular}

Notes: Robust standard errors are in parentheses: * $p<0.1 ; * * p<0.05 ; * * * p<0.01$. Total expenditures and GEJE grant are per capita and measured in thousand yen unit; Taxable income is per taxpayer and in thousand yen unit.

As can be seen in Table 3, the spatial lag coefficients Lambda in all three models are positive and statistically significant at common standard levels, indicating presences of spatial interaction among the municipalities in deciding their spending. Specifically, in model (1), the coefficient estimate is small and statistically significant at $10 \%$. The coefficient signifies that every one-unit increase in municipality $i$ 's neighbors is, ceteris paribus, associated with an increase of about $17.7 \%$ in municipality $i$ 's spending. In the cases of models (2) and (3), the Lambda coefficients are much larger, statistically significant at $1 \%$ level, and suggest corresponding figures of $73.8 \%$ and 58\% respectively. Coefficients of the cumulative debt rates are negative and significant at $1 \%$ in all models, evidencing that an increase of municipal cumulative debt rates, ceteris paribus, brings about a decrease in municipal spending. The spatial error coefficient Rho is positive and 
statistically significant at $5 \%$ in model (1), but is less statistically significant and turn negative in model (2) and (3). In all models, the coefficient estimates of Rho signify that there are spatially correlated disturbances affecting the local expenditures of the municipalities. Those disturbances could be unobserved factors like fiscal or other policy interventions from central or/ and prefectural governments.

Table 4. Spatial interactions in total expenditures among the Japanese municipalities (ML)

\begin{tabular}{lccc}
\hline$\Delta$ Total expenditures & $\Delta \mathbf{2 0 1 0 - 2 0 1 2}(\mathbf{4})$ & $\Delta \mathbf{2 0 1 2 - 2 0 1 4}(\mathbf{5})$ & $\Delta \mathbf{2 0 1 4 - 2 0 1 6}(\mathbf{6})$ \\
\hline$\Delta$ Population density & $-4.942 * * *(0.474)$ & $0.216(0.292)$ & $-1.413 * * *(0.227)$ \\
$\Delta$ Share of population $<15$ & $0.107 * * *(0.037)$ & $-0.076 * * *(0.028)$ & $0.014(0.024)$ \\
$\Delta$ Share of population $>65$ & $-0.002(0.022)$ & $0.018(0.011)$ & $0.009(0.008)$ \\
$\Delta$ Taxable income & $1.678 *(0.674)$ & $0.277(0.330)$ & $0.063(0.216)$ \\
$\Delta$ Unemployed rate & $0.009(0.015)$ & $0.020(0.014)$ & $0.022(0.017)$ \\
$\Delta$ Grant ratio & $0.009 * * *(0.001)$ & $0.004 * * *(0.001)$ & $0.002(0.001)$ \\
$\Delta$ Cumulative debt rate & $-0.012 * * *(0.001)$ & $-0.008 * * *(0.001)$ & $-0.007 * * *(0.000)$ \\
$\Delta$ GEJE grant & $0.013(0.011)$ & $0.002(0.007)$ & $0.017 * *(0.006)$ \\
Houses destroyed & $0.002(0.005)$ & $-0.003(0.002)$ & $-0.001(0.002)$ \\
Lambda & $0.121(0.069)$ & $0.515 * * *(0.079)$ & $0.410 * * *(0.091)$ \\
Rho & $0.498 * * *(0.120)$ & $-0.423 * *(0.169)$ & $-0.206(0.191)$ \\
Observations & 363 & 363 & 363 \\
\hline
\end{tabular}

Notes: Robust standard errors are in parentheses: $* p<0.1 ; * * p<0.05 ; * * * p<0.01$. Total expenditures and GEJE grant are per capita and measured in thousand yen unit; Taxable income is per taxpayer and in thousand yen unit.

Table 4 exhibits robustness check's results estimated by maximum likelihood estimators. Coefficients of Lambda in models in Table 4 are comparable to their counterpart coefficients in Table 3. The strengths of strategic interactions in ML are consistent with those of GS2SLS estimation.

There are two possible sources for strategic interactions among the municipalities in the study. First, in the Japanese political context, yardstick competition can make municipalities look around for referencing others' decisions when they are to make fiscal decisions. In order to increase the chance of being re-elected, the municipal politicians mimic policies of their neighboring jurisdictions. Previous studies that show an agreement with this argument include, but not limited to, Hayashi and Yamamoto [15], and Kim and Park [16]. The other feasible explanation could be a cooperative mechanism of municipalities. The earthquake may destroy infrastructures that are located in or managed by multiple municipalities, such as expressways and social houses. In this situation, a co-spending mechanism among municipalities is needed to repair or reconstruct the infrastructures.

\section{Conclusion}

The study has empirically investigated the strategic interaction among municipalities regarding per capita total municipal spending, using quasi-experiment spatial econometric approach. Spatial autoregressive model with spatial error correlation was chosen for econometrics analysis following valid tests. The model was estimated by both Generalized Spatial Two-Stage Least Squares and Maximum Likelihood estimators. The results from both estimation methods support each other, suggesting a positive and statistically significant spatial strategic interaction among municipalities that are geographically close to each other. The strengths of interactions were strong and highly statistically significant during the periods from 2012 to 2014 and from 2014 to 2016. The study also proposes yardstick competition and 
cooperative mechanism are the two possible sources for strategic interaction among the municipalities on total spending in the study period.

The study carries policy implication to the central government in allocating finances across municipalities. In other words, strategic interaction among the municipalities should be taken account in order to make effective local fiscal policies. The study has succeeded in finding evidence of strategic interaction among neighboring municipalities in setting their local expenditures. However, the above results are drawn from a merely country-based in a certain period. The strengths and sources of strategic interactions could vary across countries and time frames. Further studies on other country-specific data along with different quasi-experiment cases are highly recommended. Lastly, the inclusion of variables on political affiliation and election time could better explain whether yardstick competition is a source of strategic interaction among the local governments.

\section{REFERENCES}

[1] A. C. Case, H. S. Rosen and J. R. Hines, "Budget spillovers and fiscal policy interdependence. Evidence from the states," Journal of Public Economics, vol. 52, no. 3, pp. 285-307, doi: 10.1016/0047-2727(93)90036-S.

[2] J. A. Granado, J. Martinez-Vazquez, and R. R. Simatupang, "Local government fiscal competition in developing countries: The case of Indonesia," Urban Public Economics review, no. 8, pp.13-45, 2008.

[3] D. Bartolini and R. Santolini, "Political yardstick competition among Italian municipalities on spending decisions," The Annals of Regional Science, vol. 49, pp. 213-235, 2012, doi: 10.1007/s00168-011-0437-5.

[4] J. Lundberg, "Spatial interaction model of spillovers from locally provided public services," Regional Studies, vol. 40, pp. 631-644, 2006.

[5] J. Gu, "Spatial dynamics and determinants of county-level education expenditure in China," Asia Pacific Education Review, vol. 13, no. 4, pp. 617-634, 2012, doi: 10.1007/s12564-012-9224-y.

[6] Š. Lenka, "Spatial Interdependence of Local Public Expenditures: Selected Evidence from the Czech Republic," Czech Economic Review, vol. 3, no. 1, pp. 07 - 25, 2009.

[7] J. Wang, "Strategic interaction and economic development incentives policy: Evidence from U.S. States," Regional Science and Urban Economics, vol. 68, pp. 249-259, 2018, doi: 10.1016/j.regsciurbeco.2017.11.007.

[8] S. Gibbons and H. G. Overman, "Mostly Pointless Spatial Econometrics?" SERC Discussion Papers 61, UK Spatial Economics Research Centre, 2010.

[9] T. Lyytikainen, "Tax competition among local governments: Evidence from a property tax reform in Finland," Journal of Public Economics, vol. 96, pp. 584-595, 2012.

[10] F. M. Fossen, L. Mergele, and N. Pardo, "Fueling fiscal interactions: Commodity price shocks and local government spending in Columbia," International Tax and Public Finance, vol. 24, pp. 616-651, 2017.

[11] T. Miyazaki and M. Sato, "Empirical studies on strategic interaction among municipality governments over disaster waste after the 2011 Great East Japan earthquake," Journal of the Japanese and International Economies, vol. 44, pp. 26-38, 2017.

[12] H. H. Kelejian and I. R. Prucha, "A generalized two-stage least squares procedure for estimating a spatial autoregressive model with spatial autoregressive disturbances," Journal of Real Estate Finance and Economics, vol. 17, no.1, pp. 99-121, 1998.

[13] H. H. Kelejian and I. R. Prucha, "Specification and estimation of spatial autoregressive models with autoregressive and heteroskedastic disturbances," Journal of Econometrics, vol. 157, pp. 53-67, 2010.

[14] I. Arraiz, D. M. Drukker, H. H. Kelejian, and I. R. Prucha, "A spatial Cliff-Ord-type model with heteroskedastic innovations: Small and large sample results," Journal of Regional Sciences, vol. 50, no. 2, pp. 592-614, 2010.

[15] M. Hayashi and W. Yamamoto, "Information sharing, neighborhood demarcation, and yardstick competition: an empirical analysis of intergovernmental expenditure interaction in Japan," International Tax and Public Finance, vol. 24, no. 1, pp. 134-163, 2017, doi: 10.1007/s10797-016-9413-4.

[16] S. Kim and S. Park, "Are spending patterns of local government independent? Strategic interactions of U.S. local governments in California," Lex Localis - Journal of Local Self-Government, vol. 17, no. 1, pp. 121-137, 2019. 